\title{
The Impact of Cross-border Mergers on Co-decision Making The Case of a Danish company
}

\author{
Rocha, Robson
}

Document Version

Final published version

Publication date:

2008

\section{License \\ CC BY-NC-ND}

Citation for published version (APA):

Rocha, R. (2008). The Impact of Cross-border Mergers on Co-decision Making: The Case of a Danish company. Department of Business and Politics. Copenhagen Business School. Working Paper / Department of Business and Politics No. 58

Link to publication in CBS Research Portal

\section{General rights}

Copyright and moral rights for the publications made accessible in the public portal are retained by the authors and/or other copyright owners and it is a condition of accessing publications that users recognise and abide by the legal requirements associated with these rights.

\section{Take down policy}

If you believe that this document breaches copyright please contact us (research.lib@cbs.dk) providing details, and we will remove access to the work immediately and investigate your claim. 
Copenhagen Business School

HANDELSHØJSKOLEN

Department of Business

and Politics

Steen Blichers Vej 22

DK-2000 Frederiksberg

Tel. +45 38153585

Fax. +45 38153555

e-mail dbp@cbs.dk

The impact of cross-border mergers on co-decisionmaking process: the case of a Danish company

Robson Rocha, PhD 
Working paper no 58, 2008

Editor: Lars Bo Kaspersen

Department of Business and Politics

Copenhagen Business School

Steen Blichers Vej 22

DK-2000 Frederiksberg

Phone: +45 38153585

E-mail: dbp@cbp.cbs

www.cbs.dk/dbp

ISBN 87-91690-69-2 
The impact of cross-border mergers on co-decisionmaking process: the case of a Danish company

Robson Rocha, PhD

Assistant Professor

International Center for Business and Politics

Working paper

2008 


\title{
The impact of cross-border mergers on co-decision-
}

\author{
making process: the case of a Danish company
}

\begin{abstract}
The present article investigates changes over time in the patterns of co-decisionmaking in a Danish multinational company which has grown through cross-border mergers and acquisitions. The findings show the difficulties that trade union representatives face when firms try to introduce a governance regime based on shareholder value ideology. The article argues that hybrid forms of governance are unlikely to develop due to historically embedded governance institutions, which create distinct expectations about how a firm must be governed and who has the right to participate in this governance. The spread of the Anglo-Saxon model of governance in Europe is likely to have negative effects on co-decision-making processes and established patterns of organizational cooperation.
\end{abstract}

Key words: multinational corporations, mergers and acquisitions, co-decision making, institutions, corporate governance.

\section{Introduction}

Over the past several decades, mergers and acquisitions (M\&As) have become the most prevalent form of growth and internationalization strategies for multinational companies (MNCs) all over the world. During the 1990s, the total number of corporate takeovers between companies of different national origins grew more than six-fold (Kang and Johansson, 2000), the largest proportion of cross-border M\&As having taken place among European countries (OECD, 2003: 158n). These new forms of growth and internationalizing are likely to affect established relations between management and workers in the companies that are acquiring and being acquired. However, the consequences for co-decision-making in M\&As have not been studied from an institutional perspective, and this requires greater research effort (Shimizu et al., 2004: 348).

Patterns of decision-making have taken a number of different directions, progressing at different paces according to institutional environments and specific national paths. Due to the increasing number of cross-border M\&As among multinational corporations (MNCs), the encounter between different national traditions of employee influence in organizational decision-making is becoming more common than ever. These encounters develop into complex social processes, since a multiplicity of actors with different national backgrounds is involved in coordinating and controlling multinational companies (Morgan, 2001). 
Most research on M\&As has examined this phenomenon in the context of national M\&As, all of which involve changes in which conflict, tension, and power struggles are typical and expected. However, few studies have considered M\&As in a crossborder perspective or for the possible impacts on decision-making processes. Crossborder M\&As have been studied from a cross-cultural perspective in a business setting in which control mechanisms need to be negotiated between the different actors involved (Gertsen et al., 1998). Olie (1994) pointed that the degree of compatibility of administrative practices, management styles, organizational structures or organizational culture are important factors for successful integration in mergers and acquisitions. Kristensen and Zeitlin (2005), in their extensive study, have demonstrated the problematic nature of mergers and acquisitions because actors who have learned to play strategic games in their own local and national contexts need to deal with actors from other parts of the world where different rules prevail.

The present article does not focus on the cultural dimensions of or cultural integration into M\&As, but on how institutional heritage, or, as they have been called, different nationally bounded administrative heritages (Bartlett and Ghoshal, 1989; Calori et al., 1997), might affect established patterns of co-decision-making. The aim of this article is therefore to investigate changes in co-decision-making processes when companies with different institutional heritages merger and how these changes may have implications for other organizational areas. The article seeks to answer the following questions: How do established patterns of decision-making evolve in a company resulting from cross-border M\&As? If changes in decision-making processes take place, which other organizational areas are affected?

In order to investigate changes in co-decision-making in MNCs, the article focuses on one particular case that has not often been studied, namely a Danish family-owned $\mathrm{MNC}$ which in recent decades has grown through processes of merger and acquisition between companies originally from Denmark, Germany and the US. In the process it has decided to introduce an American-inspired governance model, selecting American managers for top management positions and moving its headquarters to the US.

The article shows how the introduction of a new, more top-down and centralized process for decision-making negatively affects established patterns of cooperation between managers and workers' representatives, and how these changes in turn affect the flow of information among different organizational levels and the politics of skills development within the firm. It is argued that the introduction of a new governance model based on shareholder value ideology affects established patterns of codecision-making

The article is organized as follow. First, it presents the institutional differences between liberal market economies and co-ordinated market economies which are thought to impact on the governance of firms, established patterns of co-decisionmaking and the politics of skills formation. The governance models, industrial relations systems and structures of vocational and training systems (VET) in different institutional environments are briefly discussed. Secondly, the methodology of the research is presented. Then the focus turns to the specific case study, including the history of the merger, and identifying which organizational areas are affected by codecision-making. It is shown that a firm's strategy and politics of skill formation and its efforts to improve the employability of employees are quite interdependent areas. 
The empirical material is presented in two different organizational phases, before and after the merger. By dividing the empirical material in this way, it will be shown how changes in decision-making processes affect organizational interdependencies between co-decision-making and the politics of skills formation. Finally, the findings are discussed.

\section{Danish and American business systems and co-decision- making processes.}

The analysis below uses the historical neo-institutionalist approach, which treats social actors as acting within a framework of embedded economic relations, influenced by a particular set of national institutional arrangements. Institutional arrangements can both constrain and enable action by erecting barriers but also creating opportunities for the development of employee influence in decision-making. Institutional arrangements as reflected in national legislation, the nature of property rights, and the nature of educational and vocational systems shape the boundaries and possible paths for legitimate action. National institutions create the 'rules of the game' by which individuals and organizations operate, cooperate and compete. They forge the ways in which organizations come into existence and develop (North, 1990). Institutions generate shared, collective understandings or rules of conduct reflected in laws, governance mechanisms and the functioning of financial markets (North,1990; Scott, 2001), which help to define observed patterns of market exchange (Fligstein 1996).

Governance systems and channels of co-decision-making are forged by a configuration of institutions involved in industrial relations, training systems, state interventions and financial intermediation (Whitley, 1999). Thus, governance models present features - strengths and weaknesses - that are related to the institutions in which they are embedded. The understanding of governance models in this article is based on the stakeholder approach, which is more common among economic sociologists. Corporate governance focuses on an "entire network of formal and informal relations which determines how control is exercised within corporations and how the risks and returns are distributed between various stakeholders" (Lane, 2003: 82).

The dominant practices of firms in relation to governance models, co-decisionmaking, work systems, reward systems and employee relations complement each other, thus forming distinctive national configurations (Whitley 1999). As firms are created and grow in specific institutional environments, during the process of internationalization they will bring with them the institutional distinctiveness of their home environments, or what Bartlett and Ghoshal (1989) and Calori et al. (1997) have called the 'nationally-bounded administrative heritage'. As a result, MNCs need to coordinate and control relations in a variety of institutional environments which are composed of a multiplicity of embedded actors, taking with them experiences and taken-for-granted assumptions, as well as cognitive frameworks originating in distinctive institutional environments. According to this line of argument, success in transferring and integrating practices of control and coordination is influenced by the degree of institutional similarity between a firm's home country and its subsidiary's host country (Kostova, 1999). 
There is considerable evidence of this 'country of origin' effect on multinational corporations (Edwards and Ferner, 2002). The education and training of managers and representatives in their home countries is one of the most important institutional factors informing the behaviour of MNCs. Linked to the formation and training of managers are the governance models that different societies have developed (Whitley, 1999).

The countries involved in the M\&As in this case are Denmark and the US. Denmark is an example of a co-ordinated market economy (Hall and Soskice, 2001), where, among other features, participation in decision-making has been an important component of national industrial regimes. Although it has liberal labour-market characteristics such as a low level of employment security, the Danish business system is typified by a strong trade-union movement and a tradition of co-operation between labour-market actors (Madsen, 2006). In Denmark an agreement establishing co-operation committees was established as early as 1947 by the labour movement and the private employers' associations. Even in highly Tayloristic industries, which historically have been characterized by strongly adversarial relations, Danish companies are moving towards greater co-operation and trust between management and labour (see Hasle and Møller, 2007: 425).

The Danish system of industrial relations is characterised by a high rate of unionization, which currently involves eighty percent of the workforce. There is a single channel for the representation of employees' interests through trade unions, which responds to sectoral-level collective bargaining and almost monopolizes representation in the workplace. At this level, the shop stewards represent the workers who belong to their trade unions, and a convenor elected from among all shop stewards represents the whole workforce on the company board. Representatives have the legal right to seat on the board and have easy access to top management. By having a seat in the co-operation committees, they are able to influence corporate strategy and development (Kristensen, 2003).

An important feature of the Danish industrial-relations system is its "flexicurity" model. The Danish 'flexicurity' system has been characterized as combining labourmarket flexibility and social security (Madsen, 2006). An important feature of this system is argued to be employers' ability to hire and fire employees easily. However, an important, if not the most important effect of the 'flexicurity' system in recent years has been workers' ability to upgrade their skills through continuous training, not only during periods of unemployment, but also at different stages in their working careers. What employees expect from their employers is support to upgrade skills which can be applied in current or future jobs. Danish trade unions are strongly involved in the governance of vocational and further training institutions (Kristensen and Rocha, 2007), which need to be co-ordinated locally by networks among the convenors and shop stewards of different firms, who in this way become important gatekeepers of the flexicurity system. Vocational education and training (VET) in Denmark is formed by network of organizations, with connections at different levels, where goals and means are continually being negotiated, and receiving inputs from a myriad of workplaces, trade unions and employer associations. The Minister of Education determines the guidelines for each VET program based on the recommendations of these groups, who are able to analyze labor market trends and 
recommending new programs and changes to existing ones (Winterton, 2007). The flow of information and negotiation for setting aims and means are fundamental to the well-functioning of the system, which relies on collaboration and inputs from different societal levels.

The US, which is characterized as a liberal market economy (LME), has a strong antiunion tradition and a weak tendency for the participation of the workforce in decisionmaking. The literature points to several examples of American MNCs attempting to transfer their anti-union policies to their subsidiaries abroad (Muller, 1998; Ferner et al., 2005). In Denmark, Germany, Sweden, Norway and Austria, employees have legal rights to board-level representation in private firms. Symmetrically, employees in all Anglo-Saxon countries (Australia, Canada, New Zealand, the United Kingdom and United States) have no constitutional rights, and no statutory or tripartite regulation for co-determination.

The US model of corporate governance assumes norms of self-interest, opportunism and enforced compliance (Lubatkin et al., 2005: 883). Increasing shareholder value is an important driver of senior management decision-making in American companies (Froud et al., 2000). The US model has been characterized as having an 'outsider' ownership structure, in which large firms are mainly owned by private or institutional portfolio investors, with little active interest in the day-to-day management of the firm. The 'shareholder value' model of capitalism emphasizes the primacy of the interests of shareholders over other stakeholders within the enterprise.

American managers of publicly quoted corporations are inclined to maximize the net present value of the assets under their control. The proportion of profits made by American firms which is distributed to shareholders in the form of dividends and share buy-backs rose from an average of just under 50 percent in the 1960s and 1970s to around 70 percent in the 1980s and 1990s (O'Sullivan, 2000). The continuous waves of restructuring in firms guided by the ideology of American shareholder value prompted Froud et al. (2000) to predict that "late capitalism restructuring is likely to be a negative process for labour with transitory gains for capital" (ibid.: 795).

Higher-quality forms of training like apprenticeships are more prevalent in CMEs than LMEs. Apprenticeship is most extensive in CMEs, where it occupies 5 to 6 percent of civilian employees as against just 0.3 percent in the USA (Elbaum and Singh, 1995). In the US, many of the most disadvantaged workers receive little or no training at all. At the same time, pressures to maximize short-term results and the few institutional constraints on exits among economic actors discourage long-term investments in technology and training. Many US companies are avowedly antiunion, many pursue a 'three-lane low road' of low trust, low skills, and low wages (Milkman, 1998). A race to the bottom, based on low wages and poor working conditions, is more likely to occur here.

Other characteristics of American MNCs include the centralization, standardization and formalization of HR policy (Child et al., 2000). Clark and Almond (2006) argue that American firms are less tolerant of institutional constraints, even more so than in other LMEs. On the other hand, American firms make more frequent and significant changes to their strategies, structures and practices than companies originating in socalled 'co-ordinated market economies' (CMEs) (Edwards et al., 2005; Hall and 
Soskice, 2001). This feature would facilitate American firms introducing the characteristics of a foreign model, and along with this, the hybridization of different governance models (Pieterse, 1994).

Due to the clear differences between the institutional environments involved, the expectation was that managers and labour representatives in Denmark were likely to face problems in creating coherent relationships among the different organizational levels and actors involved. However, the potential for reverse diffusion (Edwards et al., 2005) also exists, i.e. in the American company learning and adapting some governance features from the Danish company. A third possibility, a hybrid (Pieterse, 1994) form of governance, could also emerge, in which practices developed in one institutional environment are transferred to another and both experience adaptation through their recombination with home-country governance practices (ibid.: 165). Based on a longitudinal and in-depth case study, the article presents evidence that hybrid forms of corporate governance are difficult to produce due to historically embedded institutions which create distinct expectations about how a firm must be controlled and who has the right to exert this control.

\section{Research Methods}

The interest of this research was on the phenomenon of cross-border mergers and its implications for decision-making processes. The research approach was case studybased. The example here involves an in-depth case study, covering a period of three years. It describes the experience and determines the extent to which existing theories help us understand such cases or require modification (Eisenhardt and Graebner, 2007). The case-study methodology is useful in developing a processual and holistic approach (Elias, 1978) which fits well with neo-institutional theory. Case studies permit a deep exploration of how the institutional contexts in which MNCs are embedded impact on the way they are controlled and coordinated (Edwards et al., 2007).

\section{Data Collection}

Data was collected using three techniques: (1) semi-structured, one-to-one interviews, (2) semi-structured group discussions (3) written and electronic documentation, and (4) non-participant observation. Interviews were the main source of data, with the observation and documentation data serving as important triangulation and supplementary sources for understanding the phenomena.

The informants were chosen according to guidelines for "purposeful sampling" (Lincoln and Guba, 1985) using a "snowball or chain sampling" strategy. In other words, the author chose informants who would be most able to inform on the main research question concerning changes in decision-making processes over time. Past research and current research focuses suggested that sampling should begin with managers and shop stewards because they are key actors in the organizational decision-making process. During the interviews, each informant was asked for his or 
her recommendations as to who could best explicate the processes of interest. The research process involved an iterative process of collecting data, analyzing them, and looking for new informants on the basis of information considered important during the previous interviews. This strategy has made it possible continually to improve both the focus of the research and the quality of the data being collected.

The company was visited several times during the three-year period, and the research design was divided into three phases. ${ }^{1}$ During the first phase, workers, representatives and managers from different departments and hierarchical levels were interviewed. The interviews were semi-structured, and the intention was to provide an overview of current organizational processes. During the second phase, one week of very intense fieldwork was carried out in the company, with workers, top and middle managers, HR consultants, shop stewards and the convenor being interviewed. This was important in strengthening the validity of the conclusions through the use of multiple sources of information, including interviewing managers and workers from different levels and departments, which also helped to perform triangulation in the data analysis. Several interviewees were interviewed more than once during the different phases of the project. This approach was used to acquire a deeper understanding of the social processes in the factory and to obtain additional focused data to inform, extend, and refine emerging analytical themes. During the days the author spent in the company, hours were used both to collect and to analyze the data in a continuous attempt to acquire a comprehensive view of the phenomena, also returning to the interviewees and asking for further explanation, or testing the researcher's own understandings.

Observations at the shop-floor level were also carried out and interviews conducted whenever possible. The company was prepared to provide access to documents related to investment in training, salary grades and even the firm's confidential strategies. It also supplied some quantitative data and statistics, which improved knowledge of the socio-demographic characteristics of the employees. In a third phase, the author returned to the company twice and presented the analysis, which was discussed with the groups involved in the research. During this phase, the research participants were given an opportunity to comment on the data analysis, which provided another check on validity.

The number of interviews in the different phases can be seen in Table 1.

\section{Semi-structured interviews}

Semi-structured interviews were used to provide as broad a scope as possible for the data collection. Interviews lasted 35-90 minutes. The initial interview procedure was

\footnotetext{
${ }^{1}$ This article is based on data collected as a part of a larger research project investigating organizational changes in firms located in Denmark.
} 
mostly standardized across informants. These initial interviews involved questions about personal trajectory at the company, thoughts about the company's historical evolution, changes in work organization, the decision-making process, possibilities for upgrading skills, and the involvement of representatives at different organizational levels. As knowledge about the company increased and themes emerged in the data, interviews became progressively more structured. This progressive focusing of the interviews allowed patterns of interaction across informants and consistencies and inconsistencies across different organizational levels to be identified.

\section{Data Analysis}

The case analysis was based in grounded theory methods, in which theoretical concepts and propositions emerge as the researcher gathers data and investigates phenomena. In order to discover patterns, grounded theory method uses constant comparisons and its related open and axial coding techniques: the assignment of themes and concepts to a selected unit such as sentences taken from interviews, field notes and observations. The selected concepts are analyzed and combined in the search to uncover categories, while links between different categories need to be identified and confirmed against the data. The final step attempts to integrate the categories into a theory which accounts for the phenomenon being investigated.

The collected data were coded and categorized in order to facilitate abstraction and theory construction. Coding proceeded primarily on two levels: 1) using a word list of concrete terms grounded in the data (partnership, participation, lean, Americans, Danes, cooperation, control, teams, decision-making process, trade unions, etc.); 2) using a word list of more abstract terms (governance, centralization, decentralization, short term, shareholder value, country of origin, stake-holders, etc.) arising from terms found in the literature (Eisenhardt, 1989). During axial coding, the author developed further conceptual domains by comparing themes within and between transcripts (Corbin and Strauss, 1990).

Analysis took place at different points in time: while collecting data, when returning home, and while back to the field. The construction of patterns, discovery of consistencies, attempts to integrate distinct categories, abstracting from the data, and construction of theory were guided by theory as it emerged. Data was constantly compared across informants and over time (Glaser and Strauss, 1967) as integral parts of the grounded-research process.

\section{The case}

The company under investigation is one of the largest Danish companies and is considered very influential nationally, impacting on a great number of other local companies by virtue of its national legitimacy and great economic success. The case study provides a unique opportunity to investigate the organizational changes in decision-making processes from a longitudinal perspective under the complex conditions of a cross-border merger.

During the 1990s, this Danish company (DC) started a process of multiple acquisitions. In 1998 the hydraulic division of the company was split from the mother 
company and became an independent firm (D), which merged with a German company, forming GD. Currently GD is listed on the New York and Frankfurt stock exchanges. Two shareholders, the mother Danish company and the mother German company, own $38.5 \%$ each of GD stocks. After the merger the headquarters was transferred to Chicago, and a top managerial team chosen to manage GD was formed, mostly consisting of Americans who had previously been employed at the American acquisition. The merger itself produced a succession of mutually beneficial marketing advantages for both companies, boosting sales in Europe and enabling the firm to establish a large and important share of the American market. The number of employees at the Danish site grew from 700 in 2000 to its current level of 2400 employees in 2006. Some features of GD are presented in Table 2.

Table 1. Number of interviews in the different phases Insert Tab. 1

Table 2. GD profile

\section{Findings: the two phases in the development of the case study}

In this section, the case study is presented. It shows the conflicting views of American managers and Danish representatives about the decision-making process and how these differences impact on other organizational areas. First, it shows the links between co-decision-making, information flow across different organizational levels and the politics of skills formation in the Danish site. Then, I discuss changes in the characteristics of co-decision-making when an American management team takes over and sets aside previous patterns of collaboration and co-decision-making, and how these changes affected previous politics of skills formation.

As a form for organizing and presenting the data, the data are divided into two main phases, before and after the merger, but the focus is on how managers and workers' representatives negotiated at these different moments, and how the patterns of interaction has changed over the time. The section shows how changes in co-decisionmaking were perceived by the different organizational actors.

\section{Co-decision-making and the politics of skill formation}

The factory has been under pressure to improve its production processes. It has been struggling with two models: mass production and flexible specialization. These two different ways of organizing production processes can be seen side by side in the factory. Highly Taylorised lines are integrated with highly flexible workshops in complex ways. Blue-collar jobs can range from being quite repetitive to highly flexible. The continuous upgrading of skills thus becomes an important factor for moving from the first to the second category, especially as the more repetitive jobs have continually been replaced by the use of new technologies. Thus, continuous 
upgrading of skills has become an important mechanism for increasing employability in the factory, as well as in the local labour market.

Teams were considered a key element in the organizational landscape. In order to participate in this team organization, the skills development of all members was an important focus for management. It has been accepted in recent years that workers who are stimulated by their tasks are more likely to co-operate and to contribute to achieving organizational goals than those who are not. The contributions that workers can make to improve the performance of teams and to generate and share knowledge within a community of teams must be coordinated, as they have fundamental importance for HPWS:

"We cannot have workers who leave their brains at the front door. We use a number of new concepts which are based on participation. Workers need to solve problems, and they should not ask for help all the time. In the past, unskilled workers could not touch a tool, it was forbidden. Now they must solve problems. When they cannot, at least they need to be able to understand and explain what kind of problem the machine presents." (line supervisor)

The continuous upgrading of skills has thus become quite a central issue for both workers and management. Workers need to upgrade their skills in order to improve their employability. The company needs flexible workers who can optimize its production processes. This is done by participating in courses offered by the company and by local vocational institutions.

Our data indicate that special and skilled workers repeatedly asked for courses that were closely related to their jobs, as well as ones which could improve their employability in the labour market.

"I have attended many courses, all kinds. I started here seven years ago, and I knew nothing about factories. Now, I have attended several CNC courses, I can operate most of the machines in my department, and I'm asking my representative to help me to find new courses. You cannot stop, you know; you must be prepared - the future is uncertain...." (special worker)

Workers made use of the local training institutions with the support of the company. Their intention was to enhance their employability, so that they would be able to perform a large number of tasks related horizontally and vertically to their skills and jobs.

In such a system, it is not surprising that skills development becomes an extremely important issue at the negotiating table between workers and management. It is not always possible to reconcile the different demands about which types of skills are going to benefit the company, the workers, or both. Because of their knowledge about how the vocational system can be used and transformed to serve local ambitions and needs, shop stewards become fundamental actors in negotiating with managers over which courses are more suitable in providing skills upgrading and consequently more organizational flexibility and enhanced employability for workers. The knowledge that such representatives accumulate over the years is used to make contact with the vocational training institutions in order to create courses that enable employees to 
adapt to present and future working-life situations, job specifications, or career ambitions. At the same time, they also need to help companies improve their capabilities, since they negotiate courses which can support the requirements and ambitions or both firms and workers. As one representative explained:

"When the company started talking about lean production, nobody knew what it was all about, then I asked my colleagues from other companies about lean, then I could learn about their experiences with lean. I used my contacts with the local vocational centre to design the courses necessary for our workers together with them."

By showing support for employee development, the company is likely to retain and attract the best workers locally, at the same time avoiding an image that they are preventing workers from making the best possible use of supporting welfare institutions. As one supervisor explained:

"Highly engaged special workers can not only solve small maintenance problems, they can also anticipate many others, thus saving a lot of time and resources.... Many of these engaged workers are rewarded not only with higher salaries, but also with more courses...".

\section{The politics of co-decision-making}

Recognizing that representatives strengthen the links between the work force and vocational institutions, managers welcome representatives and convenors as participants in strategy construction and its continuous re-definition. By participating in strategy construction and linking it to their experiences at the shop-floor level, representatives and convenors become fundamental partners with management in the evolution of and changes in the firm. As one middle manager explained:

"We have good relationships; we are always trying to find out a solution which can benefit both sides. This is not always possible, but it works like a bank account. You know, everybody needs to put something there. This time I need a favour from them, next time they will need something from me...and in this way we keep things going on. Many times this involves a high level of compromise."

The organization is diverse, engaged in conflicts of interest and immersed in ambiguity. The picture it provides is not one of harmony among different working groups, but of actors trying to build an organization which is striving to attain and retain mutual recognition. For these groups, recognizing their diversity of interest helps to create flexibility in an environment which requires frequent modifications or changes to formal organizational structures and management practices. One shop steward remarked of his relationship with his supervisor:

"It was not that easy in the beginning when I was elected a shop steward. Our supervisor is an old fashioned guy, we had many fights, but the truth is we are partners now, we understand each other and we respect each other. We sometimes make agreements that go beyond what people would accept as...let's say, reasonable, but it is working now...." 
Co-decision-making takes place at two different organizational levels. At the shopfloor level, representatives and middle managers work together to improve production processes, negotiating the conditions of changes and solving the practical problems which continually emerge and impact on working conditions. In order to attend to the needs of the company while at the same time fulfilling the ambitions of the work force, the convener needs to be able to influence the company's strategy. This is made possible by participating at the advisory board level. The link between the different levels is effected by the convener, who is also responsible for dealing with local training institutions in order to create new courses and even new educational programmes to suit the ambitions of the different actors. The convener, who represents all shop stewards, explained his position as follows when he was confronted with an organizational diagram:

"My position in the hierarchy depends on the issue. Sometimes I need to be allied with top managers, sometimes with middle managers, always trying to find a balanced solution for all. Fortunately, I almost never need to challenge management with action. The door is always open for me at top management, and we know the strengths and weakness of each other. If we cannot achieve an agreement at the middle, I go to the top, if not there, I go to the board."

\section{Second phase: introducing American-style management}

The merger took place in 2000, and soon afterwards the company's HQ was transferred to Chicago. The Danish plant ceased to be part of the HQ of the Danish multinational, and became to the Americans just another subsidiary among many. However, during the three first years after the merger, the Danish site functioned independently from the HQ.

"There was a lot of uncertainty after the merger, but we remained quite independent. The three years after the merger were quite intense, due to the great success of our products internationally, the great marketing synergy. Things started to change when the Americans arrived here. Before they were not only distant, but also invisible" (top manager).

In 2003, two American vice-presidents were chosen to manage the Danish subsidiary and started building a new managerial structure for decision-making and implementing lean production concepts on the site. After the merger, and in part due to the increases in production, defects and the turnover rate among employees increased. In spite of this, the factory was able maintain a high level of quality, but only at the expense of increasing costs that could not be absorbed by increasing prices, as GD was contractually committed to reducing prices by $2 \%$ annually. To approach these problems with lean methodologies seemed obvious to GD: mass production allied with quality, standardization and flexibility. Indeed, elements were already integrated into the approach that was adopted. But where organizational 
changes had always been a negotiated co-designing process in the Danish factories, the American top management team tried to change this, as we shall see below.

\section{Changing the Decision-Making Process}

In the past, an organizational change towards a new managerial model would have been negotiated at different organizational levels and with different work groups and their representatives. Despite a formerly strong partnership between the convenor and the $\mathrm{CEO}$ and a tradition of integrated bargaining, American managers were convinced that trade-union representatives in Denmark, as in any other country, would be solely preoccupied with employment, wages and working conditions. The survival of the company, its strategy and governance should not be on the agenda of trade-union representatives. They also assumed that a Danish company should be managed like an American company in the US. The big difference, according one of the American vice-presidents, was related to the overall change after the merger from 'being the headquarters' to 'being just another subsidiary' in a much bigger corporation. This caused a change in the levels at which decisions were made, and as result some people who formerly participated were no longer included. One of the American vicepresidents expressed the changes in how trade-union representatives should be involved in the decision-making process as follows:

“... a leadership group decides to move some production from Denmark to Poland. Before we go public with that, before we reach the final conclusion, it is our obligation to sit with the union's people and talk about that, but to say that we need ask them and include their input in this strategy, it is not my understanding of the requirement... at the end of the day we are the ones who are going to make the decisions for the business".

This kind of argument was unacceptable to the convener:

"I need to know which departments are going to be outsourced. I need to know in order to negotiate a solution for workers who are employed in those departments. I need to know not in order to prevent it happening, but to create alternatives that can benefit the company and its employees. But Americans do not know the difference between communication and information.”

The information about new strategies became a formality, a way of dealing with the requirements of the law, not an organizational way to achieve a negotiated strategy.

The Americans based their strategies on their own priorities, causing intense restructuring of the new organization. The methods used to evaluate different performances changed. The first feature of the lean system that was introduced was the just-in-time information system. This enabled top management to control the results of the daily operations better than before: the production flow, the number of quality problems, the levels of buffers, etc. A huge amount of hard data started flowing daily from the production floor to the top managers. The information flowing towards the top levels became impressive, and the number of reports increased exponentially. However, the information did not return from the top. 
“... under the new system, managers are preoccupied with their own future. It is a quite individualistic way of doing things: people are not so much preoccupied with the common destiny of the company, [and] the effect is an organizational mess, each department following its own route, without much collaboration with other departments..." (factory manager)

The resistance to accepting the new governance mechanisms in the factory was strong among Danish managers. One top Danish manager, with long experience of the US, stated that:

"For a Dane to work in a American factory is like entering in a time machine. We go 15 years back in time. Why should we like this? There is nothing to learn from them (Americans). They are lagging far behind us!”

The negotiation of new organizational solutions was suppressed. Local managers and representatives both lost access to valuable information, and their ability to negotiate was continually being reduced. It became a strategy of divide and rule.

There was a lot of talk about the expectations of the American managers in relation to how other organizational actors should support their ideas and strategies. As the convenor explained:

"Americans love action, they need action all the time. We need to seat and discuss the implications of the whole process. They do not think I'm welcome to start questioning. Their expectation is that we support what they have decided. This is not the way things are done in Denmark."

As the American managers and the convenor could not agree what information they could share and what level of participation in the decision-making process the convenor should have, the collaboration between them started to deteriorate and totally disappeared after some months, turning instead into a very adversarial relationship. From the convenor's side, the new top managers, who were mostly Americans, were either unable to understand the Danish systems of co-decisionmaking, or unwilling to accept co-operation and participation at the higher organizational levels. As managers were reluctant to release the necessary information, even though this was against general agreements in Denmark, the alternative was to insist on the reinforcement of and obedience to the general agreement and the law.

The American managers learnt how to interpret the Danish law and keep furnishing the information they considered necessary to the representatives, but they did not consider it necessary for convenors and shop stewards to be active participants in the development of general strategies. Both parties seemed to take their roles for granted, that is, the roles that each side is supposed to play in their own national systems of industrial relations. The Danish convenor assumed that he had the right to participate in the process of decision-making, even when the conditions changed from the Danish factory being the headquarters of a Danish multinational corporation to being just another part of a much larger multinational corporation. The American managers, on the other hand, simply transferred their interpretations of the possibilities for co- 
operation between labour and capital from the US to this local community in Denmark.

Previous collaboration between shop stewards and Danish managers had avoided these tensions. The previous convenor argued that collaboration between managers and representatives had been working so well that he had made himself "unemployed" by decentralising most decisions to his representatives in the different departments. His job had become more focused on co-ordinating the work of the representatives, as well as on more central issues that affected the whole labour force in the firm's local sites. As the decentralization of tasks to shop stewards was already functioning well when the new convenor was elected and the American team was appointed, the changes did not have serious consequences for partnerships at the shop-floor level, which continued to function well.

In the new managerial model, information flowed much less across horizontal boundaries and instead from units to the top. This information was about magnitude and time, while the 'soft' information about processes, through which the earlier results had been achieved, ceased to flow. According to the Danes, the flow of information was not necessarily linked with communication and mutual understanding, as strategies from the higher levels were simply presented as information, not negotiated. Strategies at the shop-floor and middle levels, on the other hand, were negotiated, but not communicated to the top. Thus many new boundaries and filters in the organization were constructed, and systematic communication among work teams was weakened. A small group could form a team and become almost insulated from its surroundings. To a great extent, different work groups became independent of each other in the factory. Meeting short-term demands and deadlines became the preoccupation.

\section{Changes in the politics of skills formation}

The managerial team from Chicago started working on the idea of outsourcing some departments of the factories in Denmark. For this reason, they interpreted investment in human resources as a waste of time and resources, because several workers would soon cease to be employees of the company. One Danish top manager, who asked for an off-the-record interview, stated that the Americans had explicitly ordered that investment in human resources be slowed down, that employees were not to be seen as a priority for the development of the firm, and that blue-collar workers especially should be regarded as an easily discarded asset. From the American perspective, the previous way of upgrading skills seemed quite risky: why should a company help employees to develop skills which the company had no use for either currently or in the near future, and which could even help employees find new jobs in another company?

As information from the top ceased to flow, the previous process of shared decisionmaking went with it. The convenor lost his capacity to know in which direction the company was moving, and consequently he was unable to link the needs of the company to the needs of the workforce. Workers became confused about the future of the factory, with more speculation to go on than real information. As a result, workers were investing time and resources in following courses that could improve their 
employability without necessarily benefiting the firm. The courses being supported were aimed to deliver the minimal requirements for lean production and lean techniques. The previous innovative practices still existed, but overall coordination was difficult to maintain. One production manager explained the situation as follows:

"..the turnover rate is quite high now. The company has difficulties not only to retain but also to attract the employees that it needs. Our best employees and managers are trying to find new jobs elsewhere; the company is no longer an attractive workplace in the region."

New training for unskilled workers, aiming to train them as industrial operators, which had been very successful in other companies became a failure at GD, because GD was in a weak position to attract committed workers to attend the educational program. The education would take one and a half years, and the worker should spend several months in different departments of the company. However, workers no longer felt secure enough to commit themselves to the company for almost two years. One shop steward explained the situation as follows:

"As the company could not attract workers, then the humans resources department started sending very new and unprepared workers. Thus, the training became something for problematic workers, previous unemployed people. The result was a total failure. Nobody wants to take that training anymore."

\section{Discussion}

The case-study findings show that the hybridization of different forms of employee influence in decision-making was difficult to produce. Actors were operating in a complex net of institutional relations with quite different taken-for-granted assumptions about how a firm should be governed and who should benefit from this. Conflicting institutional legacies were clearly at play. Two different organizational dynamics in the same company were presented in the two different moments of the merger: before and after introduction of the "American management model".

In the first phase, an ongoing process of blurring boundaries among organizational and professional groups was taking place, implying a large number of new issues for the newly constituted organizational groups. Divisions that were more or less established became a matter of dispute, and strategies that seemed at face value demeaning for workers were defended by their representatives. Negotiations among actors was an important part of the organizational life in which actors could mutually influence each other's choices and strategies.

Workers continually upgraded skills and, as a result, changed the temporary nature of organizational roles, thus also affecting the boundaries between the different organizational groups. These boundaries became blurred and were continually being redefined, which in turn encouraged negotiation among different work groups and between themselves and their managers. The politics of skills formation and the negotiation of organizational change had become a multidimensional and interdependent process, one in which actors continually needed to redefine their roles and skills. The continuous transformation in the nature of skills that this process 
engendered made the links between the firm and the training institutions fundamental for workers.

Shop stewards and convenors represented a large variety of organizational groups and interests at different levels, both internally and externally; they were highly mobile and could cut across several organizational boundaries. As representatives engaged in negotiations at different organizational levels with different actors, new issues for negotiation continually emerged. This organizational mobility permitted them to gain access to and accumulate higher levels of information, which in turn reinforced their bargaining and persuasive power in the various organizational forums. Armed with this level of mobility and information, they had become able to create coalitions and partnerships and to negotiate with different actors, thus influencing organizational strategies and goals.

The company was a clear example of a new organizational form in which actors needed to show a willingness to adjust their positions constantly, thus being able to adapt their strategies when persuasive counterarguments were presented. Managers and representatives continually needed to justify their own choices to each other and to the groups they represented. This seemed to be fundamental, since the roles of managers and convenors were not clearly defined. To be involved in the continuous processes of negotiation and participation, in which apparently contradictory choices must be justified, makes the life of managers and convenors more interdependent.

If decisions are to be seen as being justified, employees need to view the decisionmaking process as responsive to their concerns, especially in relation to health, security, education and distributional issues. This does not mean that hierarchy totally disappears from organizational life. "Co-decision-making" and "hierarchy" are overlapping organizational principles which constantly challenge each other in the search for mutually acceptable solutions to pressing problems (Kristensen and Rocha, 2007). But a "command and control" management style is hardly acceptable in Scandinavian countries (Larsen and Neergaard, 2007; Isaksson, 2008).

During the second phase, the American management team appealed to legality and efficiency as sources of justification (Kely, 2004), in so doing raising questions about the whole idea of how co-decision-making should function and why it should take place. The new governance model was more top-down and centralized than the previous one, and there was not so much space for negotiation. When the co-decisionmaking was blocked at a higher level, although the systems as a whole did not collapse, the information flow and the deliberative processes became compromised to a great extent.

Danish representatives expected much more attention to the concerns of all stakeholders. As a result, the problematic areas drove the convenor to adopt a strongly adversarial position in his approach to top management. However, at the middle level the co-decision-making survived, with Danish managers becoming adversarial in relation to American managers while still maintaining their cooperative relations with the Danish representatives.

These changes adversely affected the process of skills formation and upgrading, which was a fundamental issue for representatives and the labour force. The shop 
steward was no longer able to influence how the strategies of the company and the ambitions of its labour force could be combined. Danish representatives expected greater access to information and more opportunities to influence strategies than top management were willing to provide. American managers expected support for managerial strategies without having to open the necessary channels for information and influence over the company's strategy.

In the present case, a hybridized form of governance could not emerge between the Danish and American models of employee participation in co-decision-making. Three areas of disagreement were fundamental in blocking the co-decision-making after the cross-border merger. First, there was incompatibility between the two governance regimes involved and the possibilities they engendered for the different actors to strategize. Americans were pursuing a centralized top-down model, which should be quick to change organizational processes. Danish representatives expect open channels to exist as a means of influencing decision-making processes. Secondly, the sources of legitimacy in decision-making moved from the development of the company and its work force in the long run towards the idea of creating shareholder value and ownerships rights. Thirdly, the industrial relations models involved affected how actors expected collaboration to function and how it affects the development of the local labour market. American managers in Denmark seemed constrained by the general US hostility towards unions and employee representation in MNCs (Ferner et al., 2005).

The institutional analysis was intended to uncover the basis for strategic action, the different forms of governance and the different forms of justification. Therefore, based on the analysis of this case, it is possible to argue that hybrid forms of governance are rather difficult to make sustainable and that, when they do take place, they will be intrinsically unstable. The different forms of justification for decisionmaking in different governance models are likely to produce strong incompatibilities, as the shareholder value ideology, which is so important for American management, is difficult to combine with the 'stakeholder' traditions of Scandinavian and other continental European countries. The different national industrial-relations traditions may also present incompatible features, like the resistance to trade unions that American companies share and attempt to export to their subsidiaries abroad.

As mergers and acquisitions have become the most prevalent mode of internationalization, we can assume that the problems faced by managers and representatives in our case are also becoming quite widespread. Representatives may try in different ways to convince foreign companies about the possibilities and mutual benefits of cooperation and co-decision-making. However, workers also turned down representatives whom they felt had learned to cooperate with managers in ways that were too favourable to the latter. Representatives need to attend to the increasing demands of the workforce. Local managers, on the other hand, are continually being pressured to cope with the demands of their headquarters, which is constantly drawing up new measures and benchmarks for performance, and demanding the introduction of novel human resource-management practices, so that plant organization and governance are constantly in flux and under negotiation. Thus, there are good reasons for anticipating that co-decision-making might always be unstable in this type of multinational corporation. 
As Djelic and Quack (2003a,b) have suggested, 'dominant foreign players' may become 'missionaries' of institutional change by trying to export their own national models, thus possibly being able to institutionalize their own national rules in foreign contexts. If this is the case, the spread of a 'shareholder' value ideology among continental European countries may have adverse consequences for established patterns of co-decision-making processes. Another possibility is that American companies could learn the advantages of the Continental European model, which supports the stronger involvement of workers in strategy construction.

It is also possible that in the long run both local management and trade unions may seek to expand their international networks and deploy international comparisons to influence organizational change and restructuring, or indeed seek European-level accommodations on some issues which reach across borders by using mechanisms as European works councils (Arrowsmith and Marginson, 2006; Brewster et al.,2007; Huzzard and Docherty,2005). These are interesting hypotheses which need a longitudinal research design which would focus on learning and bargaining processes in mergers and acquisitions, but these processes did not take place under the time span of research in which this article is based.

This article has pointed out an important area of research which needs further investigation: the dichotomy between home and host countries in a environment populated by companies that are the result of cross-border mergers and acquisitions, where the Anglo-Saxon governance model is considered by many firms to be the most adequate to support the internationalization process. On the one hand, the growing internationalization of American companies can be expected to impact strongly on established national patterns of co-decision-making due to incompatibilities between different industrial traditions and different management models. On the other hand, the increasing tensions between the different actors involved may generate new patterns of action among trade unions and their representatives, as the nature of national business systems has an impact on how actors perceive and accept the level of influence that they and the other actors have the right to pursue. A reaction within Scandinavian trade-union movements may also be expected to change the balance of power between multinational companies and local actors. Therefore, in the long run, local actors may also be expected to re-establish their previous ways of co-operating and influencing a firm's behaviour.

\section{References}

Arrowsmith, J. and Marginson, P. (2006) The European Cross-border Dimension to Collective Bargaining in Multinational Companies. European Journal of Industrial Relations 12( 3): 245-266. 
Bacon, N. and Storey, J. (2000) 'New employee relations strategies in Britain: towards individualism or partnership?', British Journal of Industrial Relations 38 (3): 407-29.

Bartlett, C. and Ghoshal, S. (1989) Managing across Borders: The Transnational Solution ( $2^{\text {nd }}$ edn.). Boston, MA: Harvard Business School Press.

Brewster,C. Wood, G. Croucher,R. and Brookes, M. (2007) 'Are Works Councils and Joint Consultative Committees a Threat to Trade Unions? A Comparative Analysis', Economic and Industrial Democracy. Vol. 28(1): 4977.

Calori, R. Lubatkin M. Very, P. and Veiga, J. (1997) 'Modeling the origins of nationally bounded administrative heritage: a historical institutional analysis of French and British firms', Organization Science 8(6): 681-696.

Chakrabarti, A., Hauschildt, J. and Sueverkruep, C. (1994) 'Does it pay to acquire technological firms?', $R \& D$ Management 24 pp. 47-56.

Child, J. Faulkner, D., and Pitkethly, R. (2000) 'Foreign direct investment in the UK 1985-1994: the impact on domestic management practice', Journal of Management Studies 37(1): 141-166.

Clark, I and Almond, P. (2006) 'Overview of American Business System', pp. 37-56 in P. Almond and A. Ferner (eds) American Multinationals in Europe: Managing Employment Relations across National Borders. Oxford: Oxford University Press.

Corbin J, Strauss A. (1990) Basics of Qualitative Research. Thousand Oaks, CA: Sage.

Djelic, M. L. and Quack, S. (2003a) From National Configurations to Transnational Recombination: Towards an Institutional Analysis of Globalisation in Proceedings of the 15th Annual Meeting of the Society for the Advancement of Socio-Economics (SASE), Aix-en-Provence, 26-28 June.

Djelic, M. L. and Quack, S. (2003b) 'Governing Globalisation—Bringing Institutions Back', pp. 1-34 in M. L. Djelic, and S. Quack (eds) Globalisation and Institutions-Redefining the Rules of the Economic Game. London: Edward Elgar.

DiMaggio, P.J. Powell W.W. (1983) 'The iron cage revisited: institutional isomorphism and collective rationality in organizational fields', American Sociological Review 48(2): 147-160.

Eisenhardt, K. M. (1989). 'Building theories from case study research'. Academy of Management Review 14 (4): 532-50. 
Eisenhardt, K. M. and Graebner, M. E. (2007) 'Theory building from cases: opportunities and challenges', Academy of Management Journal 50(1): 25-32.

Edwards, T. and Ferner, A. (2002) 'The renewed 'American Challenge': A review of employment practices in US multinationals', Industrial Relations Journal 33(2): 94-111.

Edwards, T., Almond, P., Clark, I., Colling, T. and Ferner, A. (2005) 'Reverse Diffusion in US Multinationals: Barriers from the American Business System', The Journal of Management Studies 42(6): 1261.

Edwards, T. Colling, T. Ferner, A.(2007) Conceptual approaches to the transfer of employment practices in multinational companies: an integrated approach', Human Resource Management Journal 17(3): 201-217.

Elias, N. (1978) What is sociology? Columbia University Press.

Ferner, A. (1997). 'Country of origin effects and HRM in multinational companies', Human Resource Management Journal 7 (1): 19-37.

Ferner, A. Almond, P. and Colling, T. (2005) 'Institutional theory and crossnational transfer: the case of "workforce diversity" policy in US multinationals', Journal of International Business Studies 36 (3): 304-321.

Fligstein, N. (1996). 'Markets as politics: a political-cultural approach to market institutions', American Sociological Review 64 (4): 656-673.

Froud, J., Haslam, C., Johal, S. and Williams, K. (2000) 'Restructuring for shareholder value and the implications for labour', Cambridge Journal of Economics 24(6): 771-797.

Geppert, M. Matten, D. and Williams, K. (2003) 'The social construction of contextual rationalities in MNCs: an Anglo-German comparison of subsidiary choice' Journal of Management Studies, 40(3): 617-641.

Gertsen, M. C., A.-M Søderberg, and J. E. Torp (eds) (1998) Cultural Dimensions of International Mergers and Acquisitions, Berlin and New York: Walter de Gruyter.

Hall, P. and D. Soskice, (eds) (2001) Varieties of Capitalism, Oxford University Press: Oxford.

Hasle. P and Møller, N. (2007) 'From Conflict to Shared Development: Social Capital in a Tayloristic Environment', Economic and Industrial Democracy 28(3): 401-429. 
Huzzard, T. and Docherty, P. (2005) Between Global and Local: Eight European Works Councils in Restrospect and Prospect. Economic and Industrial Democracy 26(4):541-568

Isaksson, P. (2008). Leading in a global age: Managing the Swedish way. Report 2008:14. Stockholm: VINNOVA.

Kang N-H, Johansson S. (2000) 'Cross-Border Mergers and Acquisitions: Their Role in Industrial Globalisation', OECD STI Working Papers 2000/1, OECD, Paris.

Kelly, T. (2004) 'Unlocking the Iron: Cage Public Administration in the Deliberative Democratic Theory of Jürgen Habermas', Administration \& Society 36 (1): 38-61.

Kostova, T. (1999) 'Transnational transfer of strategic organizational practices: A contextual perspective', Academy of Management Review 24(2): 308-324.

Kristensen, P. H. (2003) Et Græenseløst Arbejde. En fantastisk fortælling om danske tillidsvalgtes arbejde med at sikre arbejde, indflydelse og fremtid $i$ multinationale selskaber. København: Nyt for Samfundsvidenskaberne.

Kristensen, P.H. and Rocha, R. S. (2007). 'Unions in the Governance of the New Economy'. Paper presented at the Multilevel workshop University of Warwick.

Kristensen, P.H. and Zeitlin, J. (2005) Local Players in Global Games: The Strategic Constitution of a Multinational Corporation. Oxford: Oxford University Press.

Larsen, H. H. and Neergaard, B. D. (2007). Nordisk lys: Et forskningsprojekt om nordisk ledelse og ledelse i Norden. Nordiske kommunale arbejdsgiverorganisationer.

Lane, C. (2003) Changes in corporate governance of German corporations: convergence to the Anglo-American model? Competition and Governance 7(2-3): 79-100.

Lincoln, Y. S., \& Guba, E. G. (1985). Naturalistic inquiry. Beverly Hills, CA: Sage.

Lubatkin, M. H. Lane, P. Collin, J.S.O. and Very, P. (2005). 'Origins of Corporate Governance in the USA, Sweden and France',

Organization Studies 26 (6): 867-888. 
Madsen, P. K. (2006). 'How Can It Possibly Fly? The Paradox of a Dynamic Labour Market in a Scandinavian Welfare State', pp. 321-354 . in J. L.

Campbell, J. L., A. Hall, and O. K. Petersen (eds) National Identity and the Varieties of Capitalism: The Danish Experience. Montreal: McGill University Press.

Milkman, R. (1998) 'The New American Workplace: High Road or Low Road?', in P. Thompson and C. Warhurst (eds) Workplaces of the Future, pp. 25-39. Basingstoke: Macmillan.

O'Sullivan, M. A. (2000) Contests for Corporate Control: Corporate Governance and Economic Performance in the United States and Germany. Oxford: Oxford University Press.

Morgan, G. (2001) 'The Multinational Firm -Organizing Across Institutional and National Divides', pp 1-26 in G. Morgan, P. H. Kristensen, and R. Whitley, (eds) The multinational firm: organizing across institutional and national divides. Oxford: Oxford University Press.

Muller, M. (1998) 'Human resources and industrial relations practices of the UK and US multinationals in Germany', The International Journal of Human Resource Management 9(4): 732-749.

North, D. (1990) Institutions, Institutional Change, and Economic Performance. Cambridge: Cambridge University Press.

OECD (2003) OECD Economic Outlook - Volume 2003/1 No. 73, June Paris: OECD.

Olie, R. (1994) Shades of Culture and Institutions-in International Mergers. Organization Studies 15(3) : 381-405

Patton, M. Q. (1980) Qualitative evaluation methods. Beverly Hills, CA: Sage.

Pieterse, J. N. (1994) 'Globalization as hybridization', International Sociology 9(2): 161-184.

Roche, W. K. and Geary, J. (2002) 'Advocates, Critics and Union Involvement in Workplace Partnership: Irish Airports', British Journal of Industrial Relations 40(4): 659-88.

Shimizu, K; Hitt, M. A., VAidynath, D., and Pisano, V. (2004) 'Theoretical foundations of cross-border mergers and recommendations for the future', Journal of International Management 10(3): 307-353.

Scott, W.R. (1995) Institutions and Organizations. Sage: Thousand Oaks, CA. 
Stuart, M. and Martinez Lucio, M. (2002) 'Social Partnership and the Mutual Gains Organization: Remaking Involvement and Trust at the British

Workplace', Economic and Industrial Democracy 23(2): 177-200.

Trades Union Congress (1999) Partners for Progress: New Unionism in the Workplace. London: TUC.

Whitley, R. (1999) Divergent Capitalisms: The Social Structuring and Change of Business Systems. Oxford University Press, Oxford.

Whitley, R. (2001) 'How and Why are International Firms Different?' pp.2768 in G. Morgan, P. H. Kristensen, and R. Whitley, (eds) The multinational firm: organizing across institutional and national divides. Oxford: Oxford University Press.

Williams, K. and Geppert, M. (2006) 'The German model of employee relations on trial: negotiated and unilaterally imposed change in multi-national companies', Industrial Relations Journal 37(1): 48-63.

Yin, S. (2003) Case Study Research: Design and Methods. Thousand Oaks: Sage Publications. 
Tab. I

\begin{tabular}{|c|c|c|c|c|c|c|}
\hline & $\begin{array}{l}\text { First } \\
\text { Phase }\end{array}$ & $\begin{array}{c}\text { Number } \\
\text { of } \\
\text { interviews }\end{array}$ & $\begin{array}{l}\text { Second } \\
\text { Phase }\end{array}$ & $\begin{array}{c}\text { Number } \\
\text { of } \\
\text { interviews }\end{array}$ & $\begin{array}{l}\text { Third } \\
\text { Phase }\end{array}$ & $\begin{array}{l}\text { Number of } \\
\text { interviews }\end{array}$ \\
\hline $\begin{array}{l}\text { Top } \\
\text { managers }\end{array}$ & 1 & 1 & 4 & 6 & 2 & 2 \\
\hline $\begin{array}{l}\text { Middle } \\
\text { Managers }\end{array}$ & 2 & 2 & 5 & 9 & 4 & 4 \\
\hline Convenor & 1 & 1 & 1 & 2 & 1 & 1 \\
\hline $\begin{array}{l}\text { Shop } \\
\text { Steward }\end{array}$ & 1 & 1 & 2 & 4 & 2 & 2 \\
\hline $\begin{array}{l}\text { HR } \\
\text { Consultants }\end{array}$ & 1 & 1 & 4 & 4 & 2 & 2 \\
\hline Supervisors & 1 & 1 & 4 & 6 & 3 & 3 \\
\hline $\begin{array}{l}\text { Blue-collar } \\
\text { workers }\end{array}$ & 4 & 4 & 18 & 18 & 1 & 1 \\
\hline Total & 11 & 11 & 40 & 49 & 14 & 14 \\
\hline
\end{tabular}


Tab II - GD profile

\begin{tabular}{|l|l|}
\hline GD & \\
\hline Products & $\begin{array}{l}\text { Electro hydraulic motors } \\
\text { and controllers for off- } \\
\text { highway machinery } \\
\text { industry }\end{array}$ \\
\hline $\begin{array}{l}\text { Employees worldwide } \\
(2006)\end{array}$ & 9,000 \\
\hline Employees in Denmark & 2,400 \\
\hline (2006) & \\
\hline Revenue (2006) & $\$ 1,7$ billion \\
\hline
\end{tabular}

